\title{
Mini Spiritual Library As A Means To Improving The Character Of Sidamanik Public High School-1 Students
}

\author{
Joel Julian Siadari \\ \{joel.siadari@gmail.com \} \\ Postgraduate Program, Pelita Kebenaran School of Theology
}

\begin{abstract}
The aim of the current article is to study the possible improvement of character of high school students through the provision of a Mini Spiritual Library. Motivated by empathy and concern, the author wanted to improve the character of the students of Sidamanik Public High School-1 in order to counter the negative influence of various unstoppable developments in the present era. The hope was that students' character would transform in a positive way toward maturity through reading Christian motivational books. Poor reading habits, lack of facilities, family and school support, access to quality books are among the major concerns. After running a Mini Spiritual Library for 11 months, the results found were quite satisfying and fulfilling expectations, namely that the students showed improvements in reading interest, insight, religiousspiritual character, whether in the context of their families, school, organizations or among friends.
\end{abstract}

Keywords: Library, Reading, Reading, Character, Facilities, Access, Concern

\section{Introduction}

Character education for children, particularly high school students, needs serious attention from families and schools. According to the Musfiroh (2008), character refers to a set of attitudes, behaviors, motivations, and skills. Character education will embed values including the components of knowledge, awareness or willingness, and implementation these values. On the other hand, in the current times, moral values and character of students have experienced degradation due to developments. In the past, good moral values were highly esteemed, as well as respect and tolerance for others and for older people. Recently, a video of a student who dared to fight his teacher became viral in cyberspace. This is far from parents' expectations of their children. For this reason, children need to be educated to have the right character. One method of character education for adolescents that can be carried out is providing motivation and encouragement.

There was a genuine concern and a deep sense of empathy felt by the researcher for adolescent students in Sidamanik Public High School-1 in a rural, small-town sub-district, because their character had not met the expectations of their parents and teachers. The situation needed attention, the students needed care and a motivation boost in order for them to see their future far ahead and prepare a strong character to face the challenges in a world full of competition. One of the preparations is for young intellectuals to dig as much information as possible, especially reading books. Books are a common tool used to disseminate scientific knowledge which also equips people with a systematic way of thinking 
and application in real life that can be inspiring. Reading habits can also stimulate the brain to think critically and creatively which are crucial in character building.

An indicator of high reading interest is when the school library is crowded with students. According to several institutions, one of which is IKAPI, the reading interest of Indonesians is much lower than Singapore and Malaysia; it is especially lower if compared to Japan, Korea, America and Europe. In queues, on buses or trains, in airports, stations and waiting rooms, people are often seen reading. Moreover, data quoted from Kompas.com stated that in a day, the average Indonesian person only reads books less than an hour (average of 30-59 minutes), so in a year, the number of books completed is only 5-9 books. The scope of the study is the Sidamanik Public High School-1 students, in particular Christians. Based on observation, most of the students are very far from the national average. Quite possibly, there are many students who have never read a book at all outside the textbooks in school. Even more discontenting is the lack of concern of parents and teachers to provide books with the theme of Christian spiritual motivation, for which there appears to be no effort at all to instill an interest in reading among the young students. Motivation and encouragement are the elements that can make students interested in reading, especially Christian motivational books that can inspire Christians in an effort to improve good character. The hope is that these students will be able to think critically, creatively, until they ultimately have a sufficiently high level awareness. From the seemingly simple thing that is reading quality books containing motivation, inspiration, and stimulation needed to cause teenagers to be more productive. The books are not just relevant to spirituality but to all aspects of life. If character is changed toward the positive, then the person's life will yield positive results.

\section{Books Themed Motivation of Christianity}

It is natural law that a person will be moved when someone else pushes the person. As the Word of God says that iron sharpens iron, so man sharpens his neighbor (Proverbs 27:17). The authors of motivational books have such strong motivating factors that are powerful in inspiring so many readers, causing the character of people to change. Through motivational recommendations and testimonies, these motivators have given their thought in the books they write. Some worth mentioning are Joel Osteen, Rick Warren, Max Lucado, Nick Vujicic, Joyce Meyer. This is the opportunity that the writer found which compelled him to initiate the birth of a Christian Mini Spiritual Library at Sidamanik Public High School-1. There are many strong reasons for the benefits for the Christian students in reading Christian motivational books, as reported by www.kristenalkitabiah.com who posit that the character of students through reading Christian spiritual motivational books will increasingly improve, as these books can fill the function being role models as written in Scripture in 1 Timothy $4: 12$, "...but be an example to the believers in word, in conduct, in love, in spirit, in faith, in purity."

\section{Research Methods}

The research method used in this article is a quantitative with a descriptive approach. The author directly conducts interviews and a survey in which questionnaires were used as the instrument for data gathering. The questionnaires were filled by students of Sidamanik Public High School-1 who are members of the Mini Christian Library. The number of Christian 
students in Sidamanik Public High School-1 is approximately 350 students, with 99 students joining the mini library membership and returning 59 questionnaires or approximately $59 \%$ of the sample data, representing the number of members who participated in the reading. After this library has been running for 11 months, to find out the feedback on the availability of upto date Christian motivational books, a contest was held to further stimulate students' reading interest and also to find out how well they comprehended the books they read.

\section{Discussion and Survey Results}

The author took the initiative to share the questionnaire to find out more deeply what changes of character have been felt by Christian students of Sidamanik Public High School-1 before the existence of a library with the existence of a library.

Table 1. Results of survey on character of students before and after the Mini Spiritual Library

\begin{tabular}{|c|c|c|c|c|c|c|c|c|c|c|c|}
\hline No & Indicator & Level & Before & After & increment (\%) & No & Indicator & Level & Before & After & increment (\%) \\
\hline \multirow{4}{*}{1} & \multirow{4}{*}{$\begin{array}{l}\text { Reading } \\
\text { interest }\end{array}$} & Very High & 3 & 7 & 仓 133.33 & \multirow{4}{*}{7} & \multirow{4}{*}{$\begin{array}{l}\text { Value/ mark of } \\
\text { lessons result }\end{array}$} & Very High & 1 & 6 & 个ि 500.00 \\
\hline & & High & 13 & 39 & 순 200.00 & & & Quite High & 15 & 40 & 全 166.67 \\
\hline & & \begin{tabular}{|l|} 
Moderate \\
\end{tabular} & 31 & 13 & \begin{tabular}{ll|}
$\sqrt{y}$ & -58.06 \\
\end{tabular} & & & Moderate & 40 & 13 & \& -67.50 \\
\hline & & \begin{tabular}{|l|} 
Not Interest \\
\end{tabular} & 12 & 0 & औ -100.00 & & & \begin{tabular}{|l|} 
Low \\
\end{tabular} & 2 & 0 & $\eta-100.00$ \\
\hline \multirow{4}{*}{2} & \multirow{4}{*}{$\begin{array}{l}\text { Reading } \\
\text { frequency }\end{array}$} & Very Often & 1 & 3 & 合 200.00 & \multirow{4}{*}{8} & \multirow{4}{*}{$\begin{array}{l}\text { Personality and } \\
\text { Character } \\
\text { Development }\end{array}$} & Very Confident & 2 & 10 & 습 400.00 \\
\hline & & Quite Often & 8 & 39 & 个ि 387.50 & & & Quite Confident & 16 & 35 & 个 118.75 \\
\hline & & \begin{tabular}{|l|} 
Rarely \\
\end{tabular} & 42 & 715 & $\begin{array}{ll}\sqrt{3} & -64.29 \\
\end{array}$ & & & Normal & 29 & 13 & \begin{tabular}{ll|} 
I & -55.17 \\
\end{tabular} \\
\hline & & Never & 8 & 0 & $\sqrt{2}-100.00$ & & & Unconfident & 11 & 0 & \& -100.00 \\
\hline \multirow{4}{*}{3} & \multirow{4}{*}{$\begin{array}{l}\text { The effect of } \\
\text { reading on } \\
\text { the diligence } \\
\text { of worship }\end{array}$} & Very Diligent & 9 & 18 & 个ि 100.00 & \multirow{4}{*}{9} & \multirow{4}{*}{$\begin{array}{l}\text { Maximizing the } \\
\text { time }\end{array}$} & Very Efficient & 4 & 13 & 合 225.00 \\
\hline & & Quite Diligent & 19 & 34 & 个 78.95 & & & Quite Efficient & 16 & 42 & 1ि 162.50 \\
\hline & & \begin{tabular}{|l|} 
Moderate \\
\end{tabular} & 28 & 7 & $\sqrt{3}-75.00$ & & & \begin{tabular}{|l|} 
Moderate \\
\end{tabular} & 24 & 3 & $\begin{array}{ll}\text { ת } & -87.50 \\
\end{array}$ \\
\hline & & \begin{tabular}{|l|} 
Rarely \\
\end{tabular} & 3 & 0 & $\sqrt{2}-100.00$ & & & Wasted & 14 & 0 & \& -100.00 \\
\hline \multirow{4}{*}{4} & \multirow{4}{*}{$\begin{array}{l}\text { Relationship } \\
\text { with parents }\end{array}$} & Very Affectionate & 12 & 33 & 个ि 175.00 & \multirow{4}{*}{10} & \multirow{4}{*}{$\begin{array}{l}\text { Association with } \\
\text { quality people }\end{array}$} & Always & 8 & $2 \beta$ & 个ि 187.50 \\
\hline & & Quite Affectionate & 29 & 21 & \& $\quad-27.59$ & & & \begin{tabular}{|l|} 
Enough \\
\end{tabular} & 39 & 34 & \& $\quad-12.82$ \\
\hline & & Moderate & 18 & 5 & \& -72.22 & & & \begin{tabular}{|l|} 
Rarely \\
\end{tabular} & 12 & 2 & $\begin{array}{ll}y & -83.33 \\
\end{array}$ \\
\hline & & Not Affectionate & 0 & 0 & 仓 0.00 & & & Never & 0 & 0 & 令 0.00 \\
\hline \multirow{4}{*}{5} & \multirow{4}{*}{$\begin{array}{r}\text { Relationship } \\
\text { with teachers }\end{array}$} & Very Affectionate & 8 & 23 & 仓 187.50 & \multirow{4}{*}{11} & \multirow{4}{*}{$\begin{array}{l}\text { The number of } \\
\text { spiritual books } \\
\text { that were red }\end{array}$} & $>10$ books & 0 & 3 & 仓 300.00 \\
\hline & & Quite Affectionate & 28 & 25 & $\sqrt{3}-10.71$ & & & 6-10 books & 2 & 15 & 个ि 650.00 \\
\hline & & Moderate & 21 & 11 & 及 $\quad-47.62$ & & & 3-5 books & 16 & 24 & 仓 50.00 \\
\hline & & Not Affectionate & 1 & 0 & $\S \quad-100.00$ & & & $<3$ books & 40 & 17 & \& $\quad-57.50$ \\
\hline \multirow{4}{*}{6} & \multirow{4}{*}{$\begin{array}{l}\text { Interest of } \\
\text { learning }\end{array}$} & \begin{tabular}{|l|} 
Very Diligent \\
\end{tabular} & 2 & 6 & 个 200.00 & \multirow{4}{*}{12} & \multirow{4}{*}{$\begin{array}{l}\text { Application of the } \\
\text { books content in } \\
\text { real life }\end{array}$} & $80-100 \%$ & 2 & 6 & 个 200.00 \\
\hline & & Quite Diligent & 18 & 43 & 个ि 138.89 & & & $60-80 \%$ & 5 & 24 & 仓 380.00 \\
\hline & & \begin{tabular}{|l|} 
Moderate \\
\end{tabular} & 37 & 10 & 凤 -72.97 & & & $40-60 \%$ & 22 & $2 B$ & 仓 4.55 \\
\hline & & \begin{tabular}{|l|} 
Rarely \\
\end{tabular} & 2 & 0 & ת -100.00 & & & $0-40 \%$ & 26 & 2 & $\begin{array}{|ll|}\Omega & -92.31 \\
\end{array}$ \\
\hline
\end{tabular}

Of the 12 things compared to the conditions before and after the existence of the Mini Spiritual Library in SMA N 1 Sidamanik, it can be seen in percentages that there was a significant increase in reading interest and the reading frequency which was previously dominated by medium/rarely became quite high/quite often. The effect of reading on the diligence of worship which was previously dominated by moderate levels became quite diligent. Relationships with parents and teachers who were previously quite affectionate became increasingly affectionate to a very affectionate level. The interest in learning and the value of learning also changed from normal to being diligent enough so that the value of the lessons became quite high. In terms of personality and character development, beforehand it was normal to be quite confident in actualizing themselves in the school and family environment. In terms of maximizing the time previously wasted, it is now quite efficient. There is a fairly drastic increase in terms of association with quality people from being enough 
to always get along with qualified people. The number of spiritual books that were read changed in total from $<3$ books to more than 5 books. Surprisingly, there were students who had completely read more than 10 books. Finally the application of the content they read in real life was more than $40 \%$.

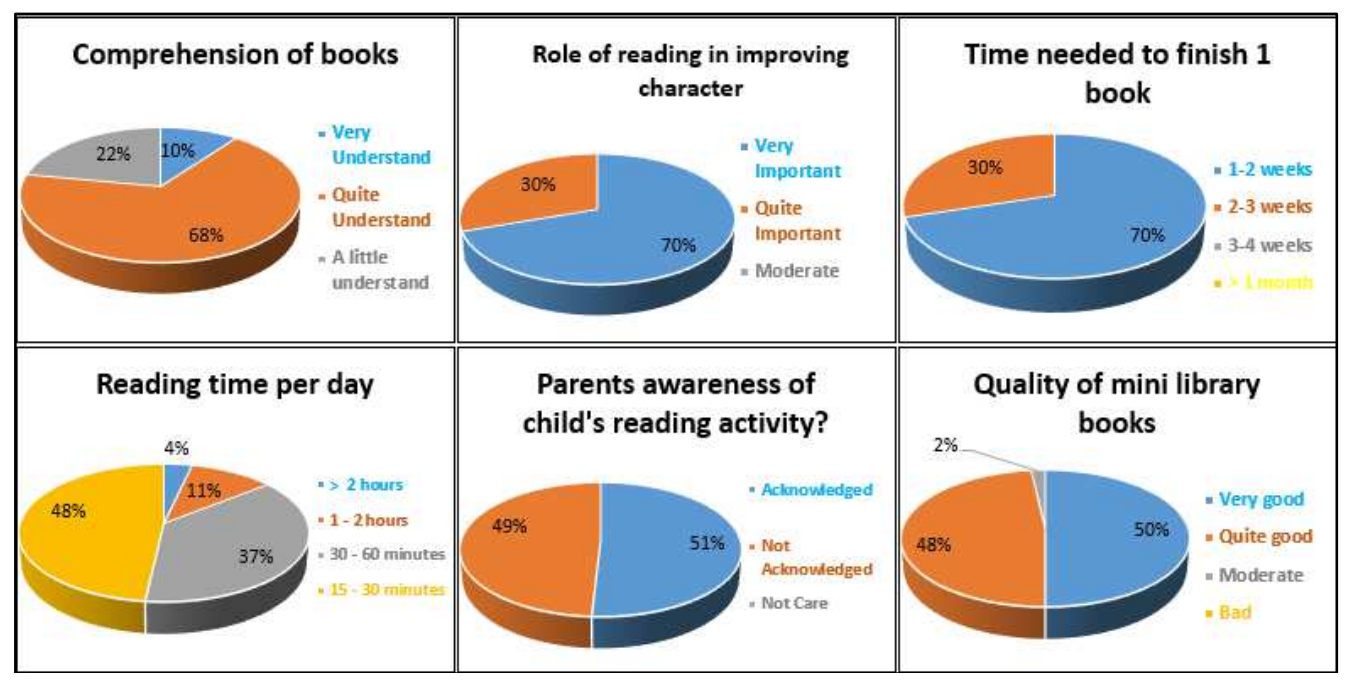

Fig 1. Survey on satisfaction and feedback on Mini Spiritual Library

The diagram above shows a satisfaction survey and feedback on the existence of a mini library that was run for 11 months. It was found that Christian students of Sidamanik Public High School-1 well understood with the books they read and they are fully aware that what they read is very important for their character development. For this reason, they tried to finish reading one book only in less than 3 weeks. However, on a daily basis their reading duration is very short due to busy school activities and home activities. They struggle to read Christian motivational books regularly in the open and known by their parents. Finally, Christian students from Sidamanik Public High School-1 considered that the quality of the library, the books, and the services of the officers were very good and very worthy to be kept running.

\section{Conclusions}

So from the 18 things surveyed by the authors that can be quantified clearly, the questionnaire data is in accordance with expectations and predictions that with the existence of a Mini Spiritual Library containing Christian spiritual motivational books, it is very clear that the improvement in students' character is seen significantly in all respects. However, this study still has many shortcomings, one of which is the language of motivational books that are still quite high level for children of high school age, so young writers/motivators should be touched to write in the language style of high school students. In addition, the authors have a desire to advance the character of students through e-books online and free but not to violate intellectual property rights/copyright. The author also realizes in this era of data technology and artificial intelligence, in the future there is potential for running online-based character improvement programs for students. 


\section{References}

[1] Kurniawan, Syamsul. 2013. Pendidikan Karakter. Pontianak: Ar-Ruzzmedia.

[2] Muslich, Masnur. 2010. Pendidikan Karakter: Menjawab Tantangan Krisis Multidimensional. Malang: Bumi Aksara.

[3] Yuldi. 2011. Memilih Buku yang Baik. Bandung: Puri Pustaka.

[4] Stobaugh R 2013 Assessing critical thinking in middle and high schools: Meeting the Common Core(London: Routledge)

[5] Mardapi D 2011 Penilaian Pendidikan Karakter, Pendidikan Karakter Dalam Perspektif Teori dan Praktik (Yogyakarta: UNY Press)

[6] Natadjumena, Rahmat. 2000. Pedoman Umum Pengelolaan Koleksi Perpustakaan Perguruan Tinggi. Jakarta: Perpustkaan Nasional RI.

[7] MacGilchrist, B 2005 Reading and achievement-some lesson for the future www.Literacytrust.org.uk Retrieved from 11 Juli 2006

[8] McNamara D S and Kendeou P 2011 Translating advances in reading comprehension research to educational practice Int. Electron. J. Elem. Educ 4 33-46

[9] Edi D.W 2010 Building The Character of The Nation In 2010-2025 (Jakarta: Pemerintah Republik Indonesia)

[10] Doni K.A 2010 Character Education, Strategy to Educate Children in The Global Age (Jakarta: Gramedia)

[11] Koesoema D. 2012 (Yogyakarta: Kanisius) Pendidikan Karakter Utuh dan Menyeluruh

[12] "Per Hari, Rata-rata Orang Indonesia Hanya Baca Buku Kurang dari Sejam." Kompas.. 26
March 2018
Web.
Februari
2019.

https://nasional.kompas.com/read/2018/03/26/14432641/per-hari-rata-rata-orang-indonesiahanya-baca-buku-kurang-dari-sejam

[13] "Budaya Membaca Penting untuk Membangun Karakter." Suara Merdeka. Insight for Living. 20 $\begin{array}{llllll}\text { September } & 2017 & \text { Web. } & 27 & \text { Februari } & 2019 .\end{array}$ $<$ https://www.suaramerdeka.com/smcetak/baca/36123/budaya-membaca-penting-untukmembangun-karakter>

[14] "20 Alasan Mengapa Kita Harus Membaca Buku-Buku Rohani.” Kristen Alkitabiah. 7 Oktober 2014. Web. 26 Februari 2018. <https://www.kristenalkitabiah.com/20-alasan-mengapa-kitamembaca-buku-buku-rohani/> 